\title{
CONVENTIONAL MINIMUM IN COPYRIGHT PROTECTION (THE BERNE CONVENTION)
}

\section{J. Barg \\ AXIOM, WROCLAW, POLAND}

Background. Intellectual property rights are present in our everyday lives to a huge extent. Law of intellectual property is generally governed by national law, with general principles set out in international treaties. Copyrights strictly protect only the expression of ideas, not the underlying ideas, procedures, methods of operation, or mathematical concepts themselves. Berne Convention was first signed in 1886 and to this day is one of the most important international treaties concerning copyrights and moral rights.

Objective. This paper aims to shortly explain the basic rights and privileges provided to the authors by the Berne Convention in its present version, i.e. Paris Act of July 24, 1971, amended on September 28, 1979.

Results. Berne Convention provides a "conventional minimum", meaning that all members must provide at least the rights granted by the Berne Convention to the authors. However, each member can grant more rights to the authors. In article 7 Berne Convention regulates the term of protection of copyrights, which is the life of the author and fifty years after her death. Moral rights, provided in Article 6bis, were added in 1928 and grant the author a right to claim authorship of the work and the right of respect. Article 10 of the Berne Convention provides "certain free uses of works".

Conclusions. The freedoms granted include possibilities of making quotations and of using the work of someone else to illustrate for teaching purposes. However, in both cases, an indication of the source of the work is required.

KEY WORDS: copyrights; moral rights; the Berne Convention; fair use.

\section{Introduction}

Intellectual property rights are present in our everyday lives to a great extent. Law of intellectual property is generally governed by national law, with general principles set out in international treaties, and by international and regional organizations such as World Trade Organization, World Intellectual Property Organization (WIPO), or European Union. The basic rights of authors are set out in the Berne Convention for the Protection of Literary and Artistic Works (the Berne Convention), which will be the baseline regarding the rights of an author, the protected works, as well as the general understanding of copyrights and moral rights of authors.

One of the most important issues regarding copyrights is that they strictly protect only the expression of ideas, not the underlying ideas, procedures, methods of operation, or mathematical concepts themselves ${ }^{[1]}$. This basically means that when one describes a method used

1 Copyright. Official website of WIPO, accessed on $24^{\text {th }}$ October 2017: http://www.wipo.int/copyright/en/ .

Corresponding author:Julia Barg, Contract Associate I., Axiom, 3, Kazimierza Wielkiego, Wroclaw, 50-077, Poland

E-mail: julka.barg@gmail.com

Phone number: +48600896343 in her experiment, only the published description is copyrighted, not the method used to obtain the results (the method could be patented, if it fulfills the patent requirements). Similarly, only the way in which the results are presented in a paper are protected by copyrights. Second important issue concerning copyrights is the fact that generally an author does not have to apply to be granted copyrights and moral rights (according to the Berne Convention, as well as in the majority of jurisdictions). Nevertheless, most countries provide a registration system in one form or another. Such systems are usually voluntary and help with licensing and transferring copyrights and in solving various disputes ${ }^{[2]}$.

The Berne Convention was first signed in 1886 and to this day is one of the most important international treaties concerning copyrights and moral rights. Not only was the Berne Convention the first international treaty relating to copyrights, but as of April 13, 2017, it has 173 members and hence applies almost all around the world. None of the international treaties provide a formal definition of copyrights, but generally such rights can be said to be 'a set of exclusive rights granted by a sovereign state to 2 Ibidem. 
an author of an original work, for a limited period of time, and within a limited area'. The Berne Convention leaves the issue of fixing the work into a tangible medium up to the national legislation of member countries ${ }^{[3]}$.

This paper will shortly explain the basic rights and privileges provided to the authors by the Berne Convention in its present version, i.e. Paris Act of July 24, 1971, amended on September 28, 1979.

\section{Author's Exclusive Rights - Conventional Minimum}

As stated above, intellectual property rights are granted at national level, rather than at the international one. Therefore, the Berne Convention provides only a so called 'conventional minimum'. All the members must provide at least the rights granted by the Berne Convention to authors. However, each member can grant more rights to the authors who seek to protect their works within that member's territory. From the rights granted to the authors by the conventional minimum, several are of greater importance with relation to publishing research and scholar papers. Provided that the author is a citizen of a member to the Berne Convention, they must be granted as a minimum the following copyrights: right of translation ${ }^{[4]}$; right of reproduction [5]; rights of adaptation, arrangement and alteration ${ }^{[6]}$; as well as moral rights ${ }^{[7]}$. There are several other copyrights set out in the Berne Convention that relate to public recitation of literary works, concerning dramatic and musical works, as well as broadcasting ${ }^{[8]}$.

The first of analyzed copyrights, the right of translation, gives the author an exclusive right to translate their original work or to give permission for someone else to translate it. The right of reproduction allows the author to grant the right to copy, reproduce, and distribute such copies of their work. Moreover, the scope of this right granted by the Berne Convention is very broad as it contains not only currently available means of reproduction and distribution but also those not yet invented ${ }^{[9]}$. Finally, the right of adaptation gives the author an exclusive

3 Berne Convention for the Protection of Literary and Artistic Works, Article 2, paragraph 2, official website of WIPO, accessed on 24th October 2017: http://www.wipo.int/treaties/ en/text.jsp?file_id $=283698$.

4 Ibidem Article 8.

5 Ibidem, Article 9.

6 Ibidem, Article 12.

7 Ibidem, Article 6bis.

8 Ibidem, Articles: 11, 11bis, 11ter, 14, 14bis, 14ter.

9 Guide to the Berne Convention for the protection of literary and artistic works (Paris Act, 1971), WIPO, Geneva, 1978, p. 54. right to change the form of their work, i.e. make a derivative work, which can be both an infringement of the primary work (if done by someone other than the author and without their consent) and an original work itself ${ }^{[10]}$.

In article 7 of the Berne Convention the term of protection of copyrights is regulated. Generally, copyrights are protected during the life of the author and fifty years after their death. As stated above, the members of the Berne Convention may provide more protection to the authors than is guaranteed in the convention but cannot breach the conventional minimum. Hence, in many member countries the term of copyright protection is longer than the conventional fifty years, i.e. in Poland, Ukraine, USA and many other countries the copyright term was elongated to the life of the author and seventy years after their death [11]. In cases of joint authorship, the copyright is protected during the lives of all authors and fifty years after their deaths. Here however, the fifty years starts to run after the death of the last surviving co-author ${ }^{[12]}$.

\section{Copyrights and Moral Rights}

In common law, copyrights tend to cover only the economic rights of the author. On the other hand, in continental law the term 'copyright' includes both economic and moral rights alike. Hence, the need to unify the protection of the authors and their rights was urgent. This was achieved by including the moral rights of authors into the conventional minimum of the Berne Convention. Moral rights, provided in Article 6bis, were added in 1928 and grant the author (i) a right to claim authorship of the work and (ii) the right of respect. Moral rights are granted to the author "independently of the author's economic rights" and exist even after the author transfers their economic rights [13]. Moreover, moral rights are maintained at least until the expiration of author's economic rights. They can also be exercised after the death of the author by "persons or institutions authorized by the legislation of the country where protection is claimed" [14].

The first of the moral rights granted by the Berne Convention, the right to claim authorship, can be exercised in many various ways. Firstly,

\footnotetext{
10 Ibidem, p. 76.

11 For more information on copyright term in various countries visit: https://en.wikipedia.org/wiki/List_of_countries\%27_copyright_lengths (accessed on 25th October 2017)

12 Berne Convention, Article 7 bis.

13 Guide to the Berne Convention, p. 42.

14 Berne Convention..., article 6bis, paragraph 2. 
the author may place their name on their work and its copies, hence claiming the authorship of the work. Secondly, the author may publish their work under a pseudonym or even anonymously. Moreover, the author can change their mind and change their pseudonym or quit their secrecy. Finally, the author can use their right in a negative way by refusing their name to be put on a work that is not theirs. The right to claim authorship is a significant issue when considering fair use and publishing the work.

The second moral right is the right of respect or, alternatively, the right to integrity of the work. According to Article $6^{\text {bis }}$ of the Berne Convention, the author can "object to any distortion, mutilation or other modification of, or other derogatory action in relation to, the said work, which would be prejudicial to their honor or reputation" [15]. This right prevents anyone from changing the work in any way without the consent of the author, even if the author transferred their economic rights. Therefore, a publisher or an editor may not delete any part from the work of the author, unless they have the author's informed and explicit consent. Even though a work is usually proofread before publication, the changes should be sent to the author for approval. Depending on the jurisdiction in which copyright protection is sought, the courts may allow some changes to be made when the work is being adapted into a different medium ${ }^{[16]}$.

One of the most important differences between the economic and moral rights of the author is the issue of transferability. Economic rights are freely transferable, while in many countries moral rights are inalienable - they stay with the author, even after licensing or transferring copyrights, and after the death of the author. This means that the author can license or sell their rights of translation, reproduction, or alteration (among others) to someone else, but they may not be able to do such a thing with their moral rights ${ }^{[17]}$. With respect to their moral rights, the author can agree not to exercise them. In many jurisdictions such a waiver must be in writing to be binding.

\section{Certain Free Uses of Works of Others}

On one hand, as authors we would like to be protected for our works, on the other - as

\footnotetext{
15 Ibidem, article 6bis, paragraph 1.

16 Cotter, Thomas F., Pragmatism, economics, and the droit moral, 76 N.C. L. Rev. 1, 1997, https://cyber.harvard.edu/metaschool/fisher/integrity/Links/Articles/cotter.html (accessed on 26th October 2017).

17 Guide to the Berne Convention..., p. 42.
}

scholars we are aware of the necessity of accessing the works of others as well as for ours to be accessed by other researchers and authors. Hence, in Article 10 of the Berne Convention provides 'certain free uses of works'. The freedoms granted include possibilities of making quotations and of using the work of someone elseto illustrate for teaching purposes. However, in both cases indication of the source of the work is absolutely required.

The Berne Convention permits quotations of someone else's work under certain limitations. Firstly, the work must have been made lawfully available to the general public, i.e. published by the author, with the author's consent, or by means of compulsory license before it can be quoted ${ }^{[18]}$. Secondly, the quotation must be "compatible with fair practice" [19]. As this concept is not defined in the Berne Convention, what is or is not fair is left for the national courts to decide. Generally, the courts will consider, among other factors, the proportion between the size of the quote and the work in which it is used ${ }^{[20]}$. Thirdly, the purpose of the quotation is also analyzed. The Berne Convention does not specify the purposes for which the quote may be used, stating only that the extent of the quote should "not exceed that justified by the purpose" [21]. Most courts assume that the purpose of the quote should be educational, scientific, analytical, or parodist. When utilizing this 'free use', the author must remember that their own work cannot be overwhelmed by the quotes. In practice it means that quotes should be put into an original work to support the ideas of the author. The resulting original work of the author cannot be a compilation of quotes, with few commentaries in between them. Rather, it should be an original work of the publishing author supported by quotes of more established researchers.

"Use of works by way of illustration for teaching" is present in copyright laws of most countries. Plainly put, the teacher may reproduce a work of someone else during her class to compare, contrast, and analyze this work. Nevertheless, the teacher must still abide by the limitations provided for quotations, i.e. the extent of the reproduction during the class must be "justified by the purpose" and the use must be "compatible with fair practice" [22]. It is worth mentioning, that the word 'teaching' includes all levels of education, i.e. "educational

18 Ibidem, p.58.

19 Berne Convention..., article 10, paragraph 1.

20 Guide to the Berne Convention..., p.59.

21 Berne Convention..., article 10, paragraph 1.

22 Berne Convention..., article 10, paragraph 2. 
institutes, municipal and state schools and private schools" [23]. Generally speaking, a professor may reproduce the work of someone else during their lecture, for example by showing a reproduction of a picture or a painting, or a fragment of a movie. Moreover, the teacher may make copies of such works (photocopies of reproductions of pictures, articles, or a page from a textbook) to be analyzed during the class, provided it is 'justified by the purpose'. Note, that you absolutely cannot photocopy and distribute more of someone else's work than is necessary to teach the class. The professor must clearly indicate the author and the source of each and every work used by the way of illustration for teaching, be it a graph, table, photo, or a sentence from someone else's work. Note, that even if the professor modifies another's work, they still must provide the source of the original work and indicate the implemented changes.

From the practical point of view, right to quote is very close in nature to the 'use of works by way of illustration for teaching' - both allow us to use the work of someone else to some extent. However, the most important purpose of copyrights is to protect economic interests of the author. Hence, in a commercial lecture we use the right to quote with the purpose being scientific or analytical rather than educational. As indicated above, with that come certain restrictions which are stricter than in case of the second fair use - in most cases the author may quote someone else's work in their commercial lecture (presentation), but most likely will be prohibited from distributing photocopies of the part of the quoted work used in the lecture.

No matter under which paragraph of Article 10 one uses someone else's work, the source and the name of the author must absolutely be mentioned ${ }^{[24]}$. Hence, article 10 paragraph 3 of the Berne Convention restates one of the moral rights of authors. The requirement to indicate the name of the author (when possible) supports the notion of the right to claim authorship. One should also note that the indication of the source may infringe the cited author's second moral right. Misrepresentation of the cited author's ideas or putting their words out of context can breach their right to integrity of their work.

\section{Conclusions}

As stated in the beginning of this article, the protection of copyrights, both economic and

23 Guide to the Berne Convention..., p. 60.

24 Berne Convention..., article 10, paragraph 3. moral rights of the authors, is within the national law. Therefore, the protections afforded to authors in public international law should be considered a set of minimum rights and privileges. The Berne Convention does not provide for an enforcement body or a court to solve the disputes that arise under copyright laws. On the contrary, in many Articles the convention leaves the means of redress for copyright infringement to national legislation and courts of the country where protection is sought.

For scholars and researchers there are some practical points that should be kept in mind. Firstly, always properly indicate the source of your quote or even paraphrase, customarily including (at least) the name of the author, the title of their work, the publisher or the title of the journal, and the year of publication. There are several styles of citation which one to use generally depends on the publisher or the university. One important tip regarding the style of citation: it should be uniform across the paper. Secondly, no matter the situation, always, always read what you agree to. When scholars submit their papers for publishing, there usually are terms of use, privacy policy, disclaimers, waivers or alike to sign or mark with annotation "I have read and agree to the following (...)". In fine print there can be hidden various waivers of copyrights, for example stating that the author licenses (or transfers) their copyrights to the publisher, or that they will not submit the paper to be published in another journal while the publication is pending in the current one or simply ever. Moreover, there can also be statements indicating that the author will not enforce their moral rights regarding this paper. As mentioned above, in many jurisdictions moral rights are inalienable - no one can demand that the author transfers or disclaims their moral rights. In such a case, only the enforcement of moral rights (in a court of law) can be disclaimed when the moral rights are infringed. Infringement can happen for example by not putting the name of the author on the work or changing the work in any way without the author's consent.

To summarize, whatever waivers or statements might be included in terms of use or publishing contract be sure to read it carefully before agreeing or signing. To be honest, it is a good idea to read a document thoroughly before signing it, whatever the circumstances. 


\section{КОНВЕНЦІЙНИЙ МІНІМУМ ЗАХИСТУ АВТОРСЬКОГО ПРАВА (КОНВЕНЦІЯ БЕРНЕ)}

Вступ. В нашому повсякденному житті, значною мірою, використовуються права інтелектуальної власності. Як правило, закон інтелектуальної власності регулюється національним законодавством, а загальні принципи викладені в міжнародних договорах. Авторські права суворо захищають лище вираження ідей, а не основні ідеї, процедури, методи роботи або самі математичні поняття. Бернська конвенція була вперше підписана в 1886 році і до цього дня є одним з найважливіших міжнародних договорів про авторські та моральні права.

Мета дослідження полягає у короткому поясненні основних прав і привілеїв, наданих авторам Бернською конвенцією уії нинішній редакції, Паризький акт від 24 липня 1971 року, змінений 28 вересня 1979 року.

Результати. Бернська конвенція передбачає «гарантований мінімум», що означає, що авторам повинні гарантуватися щонайменше права, надані Бернською конвенцією. Однак, їм такожможе надаватися більще прав. У статті 7 Бернської конвенції регулюється термін захисту авторських прав, який є життям автора і п'ятдесят років після його смерті. Моральні права, передбачені статтею бbis, були додані в 1928 році, і надають авторові право вимагати авторські права на власний твір/наукову роботу та право на повагу. Стаття 10 Бернської конвенції передбачає "безсумнівне вільне використання творів".

Висновки. Надані свободи включають в себе можливості читування і використання наукових доробків інших авторів в навчальних цілях. Проте в обох випадках обов'язково повинно вказуватися першоджерело.

КЛЮЧОВІ СЛОВА: авторські права; моральні права; Бернська конвенція; використання прав.

\section{References}

1. Copyright. Official website of WIPO, accessed on 24th October 2017: http://www.wipo.int/ copyright/en/.

2. Berne Convention for the Protection of Literary and Artistic Works. September 9, 1886, as amended on September 28, 1979. Official website of WIPO. 2017: http://www.wipo.int/treaties/en/text.jsp?file_ $\mathrm{id}=283698$.
3. Guide to the Berne Convention for the protection of literary and artistic works (Paris Act, 1971), WIPO. Geneva. 1978.

4. Cotter, Thomas F, Pragmatism, economics, and the droit moral, 76 N.C. L. Rev. 1, 1997, https:// cyber.harvard.edu/metaschool/fisher/integrity/ Links/Articles/cotter.html. Accessed on 26th October 2017.

Received: 2018-03-15 